\title{
PENGARUH DIKLAT, KEPEMIMPINAN DAN HUBUNGAN INDUSTRIAL TERHADAP KINERJA KARYAWAN
}

\author{
A.A. Hastya Priyamedha ${ }^{1}$ \\ Wayan Gede Supartha ${ }^{2}$ \\ ${ }^{1,2}$ Fakultas Ekonomi dan Bisnis Universitas Udayana (Unud), Bali, Indonesia \\ E-mail: hastyap@gmail.com
}

\begin{abstract}
ABSTRAK
Tujuan penelitian ini adalah untuk mengetahui pengatuh diklat, kepemimpinan dan hubungan industrial terhadap kinerja karyawan. Populasi dalam penelitian ini sebanyak 158 orang dengan metode penentuan sampel menggunakan purposive sampling. Teknik analisis data menggunakan regresi linier berganda. Hasil penelitian menunjukkan bahwa diklat berpengaruh positif dan signifikan terhadap kinerja karyawan. Kepemimpinan berpengaruh positif dan signifikan terhadap kinerja karyawan. Hubungan industrial berpengaruh positif dan signifikan terhadap kinerja karyawan. Praktek hubungan industrial yang kondusif dan harmonis menciptakan ketenangan bekerja sehingga dapat meminimalisir gangguan dan permasalah di lingkungan kerja. Ketika hubungan industrial ini terjaga dengan baik maka akan terjadi peningkatan produktivitas karyawan. Peningkatan produktivitas karyawan akan mempengaruhi peningkatan kinerja perusahaan. Kinerja perusahaan yang baik lebih mampu meningkatkan kesejahteraan karyawan.
\end{abstract}

Kata kunci: diklat, kepemimpinan, hubungan industrial, kinerja

\begin{abstract}
The purpose of this study is to find out about education and training, leadership and industrial relations on employee performance. The population in this study were 158 people with the method of determining the sample using purposive sampling. Data analysis techniques use multiple linear regression. The results showed that education and training had a positive and significant effect on employee performance. Leadership has a positive and significant effect on employee performance. Industrial relations have a positive and significant effect on employee performance. Conducive and harmonious industrial relations practices create a calm work so as to minimize disruption and problems in the work environment. When industrial relations are well maintained there will be an increase in employee productivity. Increasing employee productivity will affect the improvement of company performance. Good company performance is better able to improve employee welfare.
\end{abstract}

Keywords: training, leadership, industrial industrial relation, performance 


\section{PENDAHULUAN}

Dalam persaingan global dewasa ini, sumber daya manusia (SDM) memegang peranan vital dalam organisasi/ perusahaan agar mampu bersaing. Bahan baku dan sumber daya lainnya tidak akan bermanfaat bilamana kualitas sumber daya manusia tidak mendukung. Persaingan global yang semakin ketat dan diakselerasi oleh perkembangan teknologi dan infrastruktur perusahaan yang canggih menuntut perusahaan memiliki sumber daya manusia yang handal. Perusahaan dengan SDM yang berkualitas lebih mampu mengimbangi pesatnya modernisasi imfrastruktur perusahaan dan lebih berpotensi mencapai kinerja karyawan yang unggul. Perpaduan kinerja karyawan yang unggul dan infrastruktur modern bermuara pada kinerja perusahaan yang optimal (Ardianta dan Supartha, 2014).

Kinerja karyawan menjadi faktor penting dalam mewujudkan kinerja perusahaan. Kinerja karyawan merupakan output yang dihasilkan oleh karyawan pada suatu bagian dalam organisasi/ perusahaan. Bilamana output yang dihasilkan seorang karyawan sesuai atau melampaui standar yang ditetapkan perusahaan, maka Kinerja karyawan tersebut dikatakan baik. Demikian sebaliknya, bilamana hasil kerja seorang karyawan kurang atau di bawah standar yang ditetapkan perusahaan, maka Kinerja karyawan tersebut dikatakan tidak baik. Kinerja karyawan berpengaruh positif pada pencapaian tujuan perusahaan (Sriathi, 2016). Dengan demikian kinerja karyawan menjadi fokus perhatian manajerial dari manajemen di setiap perusahaan. 
Kinerja karyawan merupakan hasil kerja seorang karyawan di satu bagian dalam perusahaan (Sedarmayanti dalam Sriathi, 2016). Kinerja karyawan merupakan variabel multi dimensi, karena hasil kerja seorang karyawan dipengaruhi oleh berbagai faktor. Hasil studi literatur menunjukkan terdapat beragam variabel yang mempengaruhi kinerja karyawan, diantaranya adalah: pemberian program pendidikan dan pelatihan (diklat), motivasi, komunikasi, stress kerja, hubungan industrial, gaya kepemimpinan, program kompensasi, hubungan kerja antara karyawan dan manajemen, partisipasi karyawan dalam pengambilan keputusan, budaya organisasi, lingkungan kerja, penguasaan iptek, gaji, kompetensi, pengendalian internal, disiplin dan karakter individu masing masing karyawan.

Penelitian yang dilakukan Dartha (2017), meneliti program pendidikan dan pelatihan (diklat) terhadap kinerja karyawan, menyimpulkan bahwa diklat berpengaruh positif terhadap kinerja karyawan. Dartha (2017) meneliti diklat pegawai negeri sipil di Sekretariat Daerah Kota Malang. Demikiam juga studi yang dilakukan Pojoh dkk. (2014) terhadap para karyawan pada PT. PLN (Persero) wilayah Suluttenggo, juga menyimpulkan bahwa diklat berpengaruh positif terhadap kinerja karyawan.

Disamping penelitian yang memperlakukan diklat sebagai variabel tunggal yang mempengaruhi kinerja karyawan, terdapat juga penelitian yang memadukan diklat dengan variabel lainnya seperti; gaya kepemimpinan, hubungan kerja antara karyawan (organisasi karyawan) dengan pengusaha (organisasi pengusaha) terhadap kinerja karyawan. Berikut ini adalah penelitian yang mengkombinasikan 
A.A. Hastya Priyamedha, Pengaruh Diklat, Kepemimpinan...

pelaksanaan diklat bersama variabel lain yang diduga mempengaruhi kinerja karyawan diantaranya; penelitian Hanifah dan Nuridin (2017), Thao dan Hwang (2015), Evanita (2013), Manurung (2013), Nassazi (2013), Wiratama dan Sintaasih (2013), Setiana dan Siswandoko (2009).

Hanifah dan Nuridin (2017), meneliti pengaruh diklat dan motivasi terhadap kinerja karyawan pada PT. Synergis Global Performa, menemukan bahwa diklat berpengaruh lebih dominan dari pada motivasi. Sedangkan Thao dan Hwang (2015), meninjau variabel yang diduga mempengaruhi kinerja karyawan pada perusahaan konsultan teknik. Variabel yang diteliti adalah kepemimpinan, budaya organisasi, lingkungan kerja, motivasi dan diklat. Hasil penelitian mereka menunjukkan bahwa ada tiga variabel utama yang mempengaruhi kinerja karyawan adalah kepemiminan, motivasi dan diklat. Thao dan Hwang (2015) menekankan bahwa penguasaan teknologi baru menjadi faktor penting untuk meningkatkan daya saing perusahaan. Wiratama dan Sintaasih (2013) meneliti pengaruh kepemimpinan, diklat, dan disiplin kerja terhadap kinerja karyawan pada perusahaan air minum. Wiratama dan Sintaasih (2013) menyimpulkan bahwa baik kepemimpinan, diklat dan disiplin kerja berpengaruh signifikan terhadap kinerja karyawan.

Manurung (2013) yang meneliti variabel yang mempengaruhi kinerja karyawan yaitu; program diklat, motivasi, kepemimpinan dan budaya organisasi. Hasil penelitiannya menyimpulkan bahwa budaya organisasi, kepemimpinan dan diklat berpengaruh positif tehadap kinerja karyawan. Manurung (2013) 
menemukan bahwa budaya organisasi paling berperan dalam peningkatan kinerja karyawan, dan variabel motivasi berpengaruh positif namun tidak signifikan.

Penelitian yang dilakukan oleh Evanita (2013), Nassazi (2013) maupun Setiana dan Siswandoko (2009) dalam penelitiannya mengenai anteseden yang berpengaruh terhadap kinerja karyawan menyimpulkan bahwa motivasi, disiplin, gaya kepemimpinan dan diklat berpengaruh pada kinerja karyawan. Sedangkan penelitian Sriathi (2016) meneliti kinerja karyawan melalui pengamatan tingkat stress karyawan dan hubungan kerja diantara pekerja, pengusaha, serikat pekerja dan pemerintah. Sriathi (2016) menyimpulkan bahwa tingkat stres dan hubungan industrial berpengaruh terhadap kinerja karyawan, namun hubungan industrial lebih dominan pengaruhnya. Sedangkan penelitian yang dilakukan oleh Muda dkk. (2014) menyimpulkan bahwa stres tidak signifikan, hanya komunikasi yang berpengaruh positif terhadap kinerja karyawan.

Penelitian hubungan industrial sebagai variabel yang mempengaruhi kinerja karyawan juga dilakukan Roz (2016) yang menempatkan variabel hubungan industrial, gaya kepemimpinan transformasional dan kompensasi sebagai variabel bebas. Hasil penelitiannya menunjukkan bahwa hubungan industrial berpengaruh positif dan signifikan terhadap kinerja karyawan, sedangkan kepemimpian transformasional dan kompensasi memperkuat pengaruhnya. Baik Sriathi (2016) dan Roz (2016) menyimpulkan bahwa hubungan industrial yang terbina baik akan berkontribusi signifikan terhadap kinerja karyawan.

Mempertahankan hubungan industrial yang sehat merupakan prasyarat untuk keberhasilan organisasi. Hubungan industrial yang kuat dibutuhkan untuk 
mencapai produktivitas, kinerja karyawan dan kepuasan SDM yang tinggi. Hubungan industrial yang kuat bergantung pada lingkungan kerja yang sehat dan aman, keterlibatan dan komitmen semua karyawan, insentif untuk motivasi kerja, dan sistem komunikasi yang efektif dalam organisasi. Hubungan industrial yang sehat menyebabkan karyawan lebih efisien, termotivasi dan produktif.

Dari kajian penelitian mengenai variabel yang berpengaruh terhadap kinerja karyawan di atas yang mengambil objek penelitian pada organisasi yang beragam menunjukkan bahwa kinerja karyawan merupakan akumulasi hasil dari berbagai variabel penyebab yang sangat kompleks. Beberapa hasil penelitian menunjukkan hasil yang kontradiktif. Variabel motivasi di satu sisi ditemukan berpengaruh positif dan signifikan terhadap kinerja karyawan, sedangkan di lain pihak variabel motivasi ditemukan berpengaruh negatif. Beberapa variabel yang berpengaruh positif, signifikan dan dominan terhadap kinerja karyawan berdasarkan hasil penelitian sebelumnya adalah diklat, kepemimpinan dan hubungan industrial. Namun yang berkontribusi dominan terhadap KK pada setiap perusahaan adalah variabel yang berbeda beda.

Jadi dapat dilihat pada penelitian terdahulu tentang variabel-variabel yang mempengaruhi kinerja karyawan memiliki kesimpulan yang bervariasi. Disamping hasil penelitian yang kontradiktif, variasi objek penelitian terdahulu pada perusahaan hotel masih terbatas. Terlebih lagi industri perhotelan mendominasi industri jasa di Bali. Hotel The Royal Santrian Luxury Beach Villas, yang berlokasi di Tanjung Benoa Badung Selatan Bali merupakan salah satu perusahaan yang ikut 
bersaing dalam industri perhotelan yang juga fokus mengenai peningkatan kinerja karyawan.

Berdasarkan observasi awal, pra-penelitian melalui wawancara singkat dengan pihak manajerial diketahui tingkat kehadiran yang cenderung menurun (absensi karyawan yang relatif meningkat). Tingkat kehadiran karyawan di bulan Januari adalah 94\% (karyawan yang absen sebanyak 6\%), sementara tingkat kehadiran di bulan Juni sebesar 77,56\% (karyawan yang absen sebanyak 22,44\%). Dengan demikian terjadi peningkatan absensi karyawan. Tingkat hunian (tingkat okupansi) selama 6 bulan pertama di 2018 fluktuatif. Data pra-penelitian ini menunjukan keluhan terjadi di setiap bulan, dan tingkat turn-over karyawan yang tinggi. Sebagai mana terangkum pada Tabel 1 berikut:

Tabel 1.

Data Tingkat Okupansi, Keluhan, Kehadiran, dan Turn-over The Royal Santrian Luxury Beach Villas

\begin{tabular}{cccccc}
\hline No & Bulan & $\begin{array}{c}\text { Tingkat } \\
\text { Okupansi (\%) }\end{array}$ & $\begin{array}{c}\text { Jumlah } \\
\text { Keluhan (Kali) }\end{array}$ & $\begin{array}{c}\text { Tingkat } \\
\text { Kehadiran } \\
(\%)\end{array}$ & $\begin{array}{c}\text { Tingkat turn-over } \\
(\%)\end{array}$ \\
\hline 1 & Januari & 63,55 & 37 & 94,00 & 2,57 \\
2 & Februari & 77,68 & 78 & 90,66 & 4,00 \\
3 & Maret & 64,35 & 39 & 85,00 & 1,66 \\
4 & April & 85,67 & 55 & 88,94 & 2,00 \\
5 & Mei & 82,90 & 29 & 90,00 & 2,15 \\
6 & Juni & 82,33 & 35 & 77,56 & 1,73 \\
\hline \multicolumn{7}{l}{ Sumber: }
\end{tabular}

Diklat sangat berperan penting terhadap kinerja karyawan. Pengaruh diklat terhadap kinerja karyawan diperkuat oleh penelitian yang dilakukan oleh Dartha (2017), dan Pojoh dkk. (2014). Baik Dartha (2017) dan Pojoh dkk. (2014) berpendapat sama bahwa diklat berpengaruh positf dan signifikan terhadap kinerja karyawan. Hanifah dan Nuridin (2017), melakukan penelitian tentang pengaruh diklat dan motivasi terhadap kinerja karyawan. Penelitian mereka menunjukkan 
A.A. Hastya Priyamedha, Pengaruh Diklat, Kepemimpinan...

hasil bahwa diklat berpengaruh lebih dominan terhadap kinerja karyawan daripada motivasi.

Hidayat dan Nuraisyah (2017), menyatakan bahwa pendidikan dan pelatihan (diklat) merupakan suatu upaya dalam mengembangkan sumber daya manusia. Diklat dirancang sebagai program untuk peningkatan profesionalisme yang berkaitan dengan upaya peningkatan pengetahuan dan keterampilan karyawan. Sementara itu, Kasmuni dkk. (2016) menjelaskan pendidikan dan pelatihan secara terpisah sebagai berikut. Pendidikan berkaitan dengan upaya menambah, meningkatkan pengetahuan dan pemahaman umum mengenai satu bidang, sehingga pengetahuan dan pemahaman dalam bidang tersebut meningkat. Sedangkan pelatihan merupakan proses sistematik pengubahan, perilaku dan tindakan karyawan dalam suatu arah guna mencapai tujuan-tujuan organisasional (Kasmuni dkk., 2016). Pelatihan atau training sebagai suatu kegiatan yang bermaksud untuk memperbaiki dan mengembangkan sikap, tingkah laku keterampilan, pengetahuan dari karyawan sesuai dengan keinginan perusahaan.

Armawansyah dkk. (2016) mengemukakan pendidikan adalah suatu usaha sadar untuk meningkatkan pengetahuan seseorang termasuk di dalamnya penguasaan teori dalam menghadapi berbagai persoalan yang menyangkut kegiatan mencapai tujuan. Sedangkan pelatihan adalah suatu kegiatan untuk memperbaiki kemampuan kerja seseorang dalam kaitannya dengan keterampilan (skill). Pelatihan dapat membantu karyawan dalam penguasaan kecakapan, keterampilan dan penerapannya. Pelatihan karyawan bermanfaat dalam meningkatkan keterampilan, 
kecakapan dan kompetensi karyawan. Kecakapan dan kompetensi sangat diperlukan oleh karyawan dalam organisasi untuk mencapai tujuan organisasi.

Menurut Kasmir (2016:125) pelatihan merupakan proses untuk membentuk dan membekali karyawan dengan menambah keterampilan, kemampuan, keahlian, dan perilakunya. Pelatihan dapat membentuk perilaku karyawan yang sesuai dengan yang diharapkan perusahaan, misalnya sesuai dengan budaya perusahaan. Demikian juga Dessler (2011:280) menyatakan bahwa pelatihan merupakan proses mentransfer keterampilan yang dibutuhkan karyawan baru agar dapat melakukan pekerjaannya. Pelatihan mengacu kepada proses untuk menyiapkan atau memberikan karyawan baru kecakapan atau keterampilan yang saat itu mereka butuhkan untuk menyelesaikan pekerjaan mereka.

Sedangkan Rivai (2009:163) menyatakan pelatihan sebagai bagian pendidikan yang menyangkut proses belajar untuk memperoleh dan meningkatkan keterampilan di luar sistem pendidikan yang berlaku dalam waktu yang relatif singkat dengan metode yang lebih mengutamakan pada praktik daripada teori. Pelatihan adalah proses sistematik dalam mengubah tingkah laku karyawan untuk mencapai tujuan organisasional. Pelatihan berkaitan dengan upaya dalam meningkatkan keahlian dan kemampuan karyawan untuk melaksanakan suatu pekerjaan.

Plessis (2016) mendeskripsikan pelatihan sebagai proses pembelajaran yang didesain lebih spesifik untuk meningkatkan keterampilan dan kemampuan karyawan, agar karyawan dapat melaksanakan tugasnya dengan lebih baik. Pelatihan dimaksud untuk memperoleh persiapan dalam menentukan perilaku (pre- 
A.A. Hastya Priyamedha, Pengaruh Diklat, Kepemimpinan...

determining behavior). Pelatihan memberikan keterampilan dan pengetahuan kepada karyawan untuk dapat melakukan tanggung-jawab yang diberikan di tempat kerja. Pendidikan meningkatkan seluruh kompetensi karyawan, dimana cakupannya lebih luas dari pekerjaan yang sedang mereka lakukan.

Ardianta dan Supartha (2014), menyatakan bahwa pendidikan dan pelatihan adalah kegiatan pada suatu perusahaan dengan tujuan untuk memperbaiki dan mengembangkan sikap dan perilaku, keterampilan dan pengetahuan serta kecerdasan sumber daya manusia sesuai dengan keinginan dari perusahaan yang bersangkutan.

Menurut Falola et al. (2014), diklat merupakan suatu teknik yang digunakan untuk mengajarkan keterampilan, pengetahuan dan kompetensi tertentu dengan tujuan meningkatkan kemampuan karyawan dalam menyelesaikan tugas yang diberikan. Diklat merupakan strategi yang sangat diperlukan untuk menunjang kinerja baik itu individu maupun kelompok dalam suatu organisasi.

Berdasarkan definisi mengenai pendidikan dan pelatihan di atas dapat di jelaskan bahwa pendidikan dan pelatihan mempunyai tujuan yang hampir sama yaitu meningkatkan kualifikasi sumber daya manusia, namun demikian pendidikan dan pelatihan memiliki ruang lingkup yang berbeda. Pendidikan menekankan pada pengembangan individu secara menyeluruh seperti kemampuan kognitif, afektif, dan psikomotorik. Melalui pendidikan diharapkan agar individu bisa beradaptasi dengan baik bilamana terjadi perubahan lingkungan. Sedangkan pelatihan mengarahkan karyawan ke arah penguasaan keterampilan tertentu dan kemampuan dalam menyelesaikan tanggung-jawab yang diberikan, sehingga materi yang 
diberikan pada pelatihan bersifat sangat spesifik dan fokus penekanan lebih pada ranah psikomotorik dari pada kognitif dan afektif.

Kepemimpinan merupakan pola perilaku yang disukai pemimpin dalam proses mengarahkan dan mempengaruhi para bawahan (karyawan). Seorang pemimpin harus memperhatikan dan selalu berusaha untuk mempengaruhi dan meyakinkan karyawan agar termotivasi melaksanakan tanggung-jawabnya. Menurut Shobirin dkk. (2016), kepemimpinan adalah suatu proses kegiatan seseorang untuk menggerakkan orang lain dengan memimpin, membimbing, mempengaruhi orang lain untuk melakukan sesuatu agar dicapai hasil yang direncanakan. Purba (2016) menyatakan pendapatnya bahwa karyawan yang dapat menerima dan menjalankan dengan baik keputusan pemimpin, akan menghasilkan efektivitas dan efisiensi dalam perusahaan. Menurut Basit et al. (2017) kepemimpinan merupakan suatu pengaruh interpersonal yang dilakukan pada situasi tertentu melalui, proses komunkasi guna mencapai tujuan atau sasaran yang sudah ditetapkan.

Sedangkan menurut Kashanah dkk. (2016), kepemimpinan merupakan sifat dari pemimpin dalam memikul tanggung jawabnya secara moral dan legal formal atas seluruh pelaksanaan wewenangnya yang telah didelegasikan kepada orangorang yang dipimpinnya.

Yuliana (2016), menyatakan bahwa kepemimpinan adalah cara seorang pemimpin mempengaruhi perilaku bawahan agar mau bekerja sama dan bekerja secara efektif dan efisien untuk mencapai tujuan organisasi yang menjadi tugas dan tanggung-jawabnya. Menurut Chandra dan Priyono (2016), menyatakan 
A.A. Hastya Priyamedha, Pengaruh Diklat, Kepemimpinan...

kepemimpinan merupakan aktivitas yang dilakukan seseorang dengan cara mempengaruhi orang lain guna mencapai tujuan organisasi.

Kepemimpinan menurut Iqbal et al. (2015), merupakan proses eksekutif dalam mengarahkan, membimbing dan mempengaruhi kebiasaan bekerja bawahannya menuju pencapaian prestasi maupun tujuan organisasi dalam situasi tertentu. Kepemimpinan merupakan kemampuan seorang manajer mempengaruhi bawahannya untuk bekerja dengan semangat dan kepercayaan diri. Rathore et al. (2017), menyatakan kepemimpinan didefinisikan sebagai proses interaksi pimpinan dan bawahan dimana pemimpin mempengaruhi kebiasaan dari bawahannya untuk mencapai tujuan organisasional.

Kepemimpinan merupakan kemampuan untuk mempengaruhi kebiasaan orang lain guna mengarahkan kepada tujuan tertentu. Kepemimpinan didefinisikan sebagai proses dimana individu mempengaruhi anggota kelompok menuju pencapaian organisasi yang ada (Abadi dan Renwarin 2017).

Ardianta dan Supartha (2014), mengatakan kepemimpinan merupakan interaksi antara atasan dalam pengaruhnya terhadap bawahan atau karyawan untuk membimbing dan mengarahkan mereka dalam bekerja sebagai upaya pencapaian tujuan perusahaan. Kusumaningrum (2015) menyimpulkan bahwa variabel kepemimpinan dari pemimpin memiliki pengaruh positif terhadap kinerja karyawan. Kepemimpinan yang dapat diterima karyawan menjadikan karyawan semakin nyaman, bersemangat dan kinerjanya meningkat. Kepemimpinan merupakan suatu proses mempengaruhi dari invidu ke kelompok maupun dari 
individu ke individu, dengan tujuan mencapai tujuan yang sudah ditetapkan (Koech dan Namusonge 2012).

Heriyono (2013), menyatakan bahwa Interaksi antara karyawan (sesama karyawan) dengan pengusaha dan pemangku kepentingan terhadap perusahaan membentuk hubungan kerja dalam lingkungan kerja. Hubungan kerja tersebut dikenal dengan hubungan industrial. Hubungan industrial merupakan suatu sistem hubungan yang terbentuk antara para pelaku dalam proses produksi barang dan jasa, yang didasarkan pada nilai-nilai yang berkembang dalam masyarakat dan dimanifestasikan dalam lingkungan kerja.

Hubungan industrial memiliki peran strategis dalam dunia usaha.Hubungan industrial merupakan istilah yang menggabung berbagai isu, mulai dari perundingan, negosiasi, undang-undang tenaga kerja, hingga pertimbangan terbaru seperti work-life balance, kesempatan yang sama (equal opportunities), pengelolaan keragaman (managing diversity). Hal ini meliputi praktik untuk memastikan karyawan yang bekerja tetap senang dan produktif(Sequeira dan Dhriti 2015).

Menurut Chaudhry et al. (2013) hubungan industrial merupakan suatu praktik organisasional yang berkaitan dengan karyawan, keuntungan dan kompensasi (compentation and benefit), manajemen kinerja, pengembangan organisasi, keselamatan dan kesehatan kerja, serta komunikasi dan administrasi. (Chaudhry et al., 2013) menyatakan definisi hubungan industrial adalah pengelolaan hubungan antara karyawan dan pengusaha guna mencapai level produktivitas yang tinggi dalam hal barang dan jasa. 
Wiratama dan Sintaasih (2013), melakukan penelitian mengenai kepemimpinan, diklat, dan disiplin kerja terhadap kinerja karyawan, menunjukan ketiga variabel tersebut berpengaruh signifikan terhadap kinerja karyawan. Purba (2016), melakukan penelitian mengenai pengaruh pelatihan, gaya kepemimpinan, dan kinerja pegawai menunjukkan bahwa variabel pelatihan berpengaruh lebih dominan terhadap kinerja karyawan daripada gaya kepemimpinan.

Berdasarkan penjelasan di atas, hipotesis yang diajukan sebagai berikut:

$\mathrm{H}_{1}$ : Diklat berpengaruh positif dan signifikan terhadap kinerja karyawan.

Penelitian yang dilakukan Evanita (2013), meninjau tiga variabel yang diduga mempengaruhi kinerja karyawan yaitu disiplin kerja, gaya kepemimpinan dan pelatihan, menunjukkan ketiga variabel tersebut berpengaruh signifikan terhadap kinerja karyawan, namun pelatihan yang berpengaruh paling dominan.

Raharjo dan Sedyaningsih (2014), pada penelitiannya yang yang meneliti pengaruh kepemimpinan, motivasi, dan lingkungan kerja terhadap kinerja karyawan pada PT. Citra Sukses Eratama Tanggerang, menunjukkan bahwa ketiga variabel berpengaruh positif dan signifikan terhadap kinerja karyawan.

Wijayanti (2012), dalam skripsinya yang berjudul pengaruh kepemimpinan dan motivasi kerja terhadap kinerja karaywan pada PT. Daya Anugerah Semesta Semarang, menunjukkan bahwa variabel kepemimpinan berpengaruh positif dan signifikan daripada kinerja karyawan.

Yuliana (2016), dalam penelitiannya yang berjudul pengaruh kepemimpinan, motivasi, dan lingkungan kerja terhadap kinerja karyawan pada PT. BCA Syariah 
Semarang, menunjukkan bahwa variabel kepemimpinan berpengaruh paling dominan terhadap kinerja karyawan daripada motivasi dan lingkungan kerja.

Ardianta dan Supartha (2014), dalam penelitiannya yang berjudul pengaruh diklat, kepemimpinan, dan penerapan budaya organisasi terhadap kinerja karyawan, menunjukkan, bahwa ketiga variabel yang diteliti berpengaruh positif dan signifikan terhadap kinerja karyawan.

Berdasarkan penejelasan di atas, hipotesis yang diajukan sebagai berikut:

$\mathrm{H}_{2}$ : Kepemimpinan berpengaruh positif dan signifikan terhadap kinerja karyawan

Hasil penelitian yang dilakukan oleh Sriathi (2016), yang melakukan penelitian mengenai variabel yang mempengaruhi kinerja karyawan. Dengan meneliti variabel stres kerja dan hubungan industrial. Kesimpulan Sriathi (2016) menunjukkan bahwa stres kerja dan hubungan industrial berpengaruh signifikan terhadap kinerja karyawan baik secara parsial maupun simultan, dimana hubungan industrial berpengaruh lebih dominan.

Hasil penelitian yang dikemukakan oleh Roz (2016), dalam penelitiannya yang meninjau hubungan industrial, gaya kepemimpinan transformasional dan kompensasi sebagai variabel bebas, menunjukkan bahwa hubungan industrial berpengaruh positif dan signifikan terhadap kinerja karyawan sedangkan kepemimpinan transformasional dan kompensasi memperkuat pengaruhnya.

Hasil penelitian yang dilakukan oleh Sequeira dan Dhriti (2015), yang meneliti mengenai pengaruh hubungan industrial terhadap kinerja pada karyawan Kavya Systems, Bangalore mengatakan hubungan industrial berpengaruh signifikan terhadap kinerja karyawan. Hasil penelitiannya juga menjelaskan bahwa dengan 
meningkatkan praktik hubungan industrial yang baik dalam organisasi dapat meningkatkan kinerja karyawannya.

Kuzu dan Ozilhan (2014), meneliti tentang pengaruh hubungan industrial, knowledge sharing terhadap kinerja karyawan, pada hotel bintang lima, mengatakan hubungan industrial dan knowledge sharing berpengaruh signifikan terhadap kinerja karyawan.

Charlene et al. (2017), melakukan penelitian mengenai pengaruh hubungan industrial terhadap kinerja karyawan pada perusahaan konstruksi dan manufaktur, mengatakan hubungan industrial berpengaruh signifikan terhadap kinerja karyawan. Dalam penelitiannya juga dikatakan bahwa praktik hubungan industrial yang dilakukan oleh perusahaan sanngat dirasakan langsung oleh karyawan perusahaan, sehingga karyawan memberikan upaya terbaik dalam kinerjanya. Dengan demikian berdasarkan penjelasan di atas, hipotesis yang diajukan sebagai berikut:

$\mathrm{H}_{3}$ : Hubungan Industrial berpengaruh positif dan signifikan terhadap Kinerja Karyawan

\section{METODE PENELITIAN}

Penelitian ini dilakukan di The Royal Santrian Luxury Beach Villas yang beralamat di Jl. Pratama Tanjung Benoa Bali, dipilih sebagai lokasi penelitian dengan pertimbangan bahwa perusahaan yang bergerak pada bidang jasa pelayanan perhotelan bertujuan mendapatkan keuntungan maksimal dengan daya saing yang tinggi tanpa mengabaikan kesejahteraan karyawan sebagai salah kunci keberhasilan maupun kegagalan finansial perusahaan. 
Populasi dalam penelitian ini adalah karyawan yang bekerja pada The Royal Santrian Luxury Beach Villas, yang berjumlah 158 orang dengan proporsi sebagai berikut:

Tabel 2.

Jumlah Populasi

\begin{tabular}{ccc}
\hline No & Departemen & Jumlah Anggota \\
\hline 1 & Excecutive & 3 \\
2 & Human Resource Management & 5 \\
3 & Security & 17 \\
4 & Sales and Marketing & 6 \\
5 & Accounting & 11 \\
6 & Front Office & 26 \\
7 & Spa & 6 \\
8 & House Keeping & 11 \\
9 & Engineering & 17 \\
10 & Food and Beverage Service & 27 \\
11 & Food and Beverage Kitchen & 29 \\
& Jumlah & 158 \\
\hline
\end{tabular}

Sumber: Data diolah, 2018

Sampel yang digunakan pada penelitian ini adalah non probability sampling dengan metode purposive sampling. Penelitian ini dianalisis dengan multivariate, dimana jumlah sampel ditentukan dengan menggunakan rumus Slovin. Indikator yang digunakan dalam penelitian ini berjumlah 19 indikator, maka jumlah responden yang digunakan sebagai sampel sebanyak 113 responden. Perhitungan jumlah sampel menggunakan rumus Slovin dengan hasil sebagai berikut :

$$
\begin{aligned}
& n=\frac{\mathrm{N}}{1+\mathrm{Ne}^{2}} \\
& \mathrm{n}=\frac{158}{1+158 \times 0,05^{2}}=113 \text { Responden }
\end{aligned}
$$

Keterangan :

n: Jumlah Sampel

N: Jumlah Populasi

e: Error (Tingkat kesalahan/toleransi) 
Regresi linier berganda digunakan untuk menguji pengaruh dua atau lebih variabel bebas (independent variable) $\mathrm{X}$ terhadap variabel terikat (dependent variable) Y. Bentuk umum persamaan regresi linier berganda dengan tiga variabel bebas $\mathrm{X}_{1}, \mathrm{X}_{2}, \mathrm{X}_{3}$ dan variabel terikat $\mathrm{Y}$ digambarkan sebagai berikut:

$$
Y=a+b_{1} X_{1}+b_{2} X_{2}+b_{3} X_{3}+e
$$

Keterangan:

$\mathrm{Y}$ : variabel terikat, dalam penelitian ini adalah kinerja karyawan.

$\mathrm{X}_{1}, \mathrm{X}_{2}$ dan $\mathrm{X}_{3}$ adalah variabel bebas ke-1 ke-2 dan ke-3, berturut-turut adalah variabel kepemimpinan, diklat dan hubungan industrial.

a : konstanta

$\mathrm{b}_{1}$ : koefisien regresi variabel diklat $\left(\mathrm{X}_{1}\right)$

$\mathrm{b}_{2}$ : koefisien regresi variabel kepemimpinan $\left(\mathrm{X}_{2}\right)$

$\mathrm{b}_{3}$ : koefisien regresi variabel hubunagan industrial $\left(\mathrm{X}_{3}\right)$

e : error

\section{HASIL PENELITIAN DAN PEMBAHASAN}

Tabel 3.

Hasil Uji F (Uji Simultan)

\begin{tabular}{|c|c|c|c|c|c|c|c|}
\hline & Model & Sum of & & df & Mean Square & $\mathbf{F}$ & Sig. \\
\hline \multirow[t]{3}{*}{1} & Regression & 75.542 & 3 & & 25.181 & 73.926 & $.000^{\mathrm{a}}$ \\
\hline & Residual & 37.127 & 109 & & .341 & & \\
\hline & Total & 112.669 & 112 & & & & \\
\hline
\end{tabular}

Sumber: Data diolah, 2018

Berdasarkan hasil uji F (simultan) menunjukkan bahwa nilai F sebesar 73,926 dengan signifikan 0,000 yang nilainya kurang dari 0,05 maka keputusannya dapat dikatakan bahwa adanya pengaruh diklat, kepemimpinan, dan hubungan industrial secara simultan terhadap kinerja karyawan.

Analisis regresi linier berganda dilakukan dengan cara menganalisis diklat X1), kepemimpinan (X2) dan hubungan industrial (X3) sebagai variabel independen dan kinerja karyawan (Y) sebagai variabel dependen. Berikut tabel hasil analisis regresi linier berganda: 
Tabel 4.

Hasil Analisis Regresi Linier Berganda

\begin{tabular}{lcccccc}
\hline & \multicolumn{2}{c}{$\begin{array}{c}\text { Unstandardized } \\
\text { Coefficients }\end{array}$} & $\begin{array}{c}\text { Standardized } \\
\text { Coefficients }\end{array}$ & & \\
\cline { 2 - 5 } & $\mathbf{B}$ & Std. Error & Beta & t & Sig. \\
\hline 1 (Constant) & .271 & .236 & & 1.151 & .252 \\
Diklat & .203 & .100 & .179 & 2.028 & .045 \\
Kepemimpinan & .291 & .100 & .280 & 2.918 & .004 \\
Hubungan Industrial & .509 & .083 & .459 & 6.102 & .000 \\
\hline Sumber: Data diolah, 2018 & & & & &
\end{tabular}

Dari tabel 4 diperoleh persamaan regresi sebagai berikut:

$$
\mathrm{Y}=0,271+0,203 \mathrm{X} 1+0,291 \mathrm{X} 2+0,509 \mathrm{X} 3
$$

Berdasarkan persamaan regresi diatas, maka dapat bahwa koefisien regresi diklat (X1) menunjukkan nilai sebesar 0,203 hal ini berarti menunjukkan arah pengaruh diklat (X1) terhadap kinerja karyawan (Y) adalah signifikan positif dengan nilai signifikansinya 0,045 lebih kecil dari 0,05 . Hal ini pengaruh diklat berbanding lurus terhadap kinerja karyawan, artinya semakin baik diklat yang diberikan oleh perusahaan maka semakin baik pula kinerja karyawannya.

Koefisien regresi kepemimpinan (X2) menunjukkan nilai sebesar 0,291 hal ini berarti menunjukkan arah pengaruh kepemimpinan (X2) terhadap kinerja karyawan (Y) adalah signifikan positif dengan nilai signifikansinya 0,004 lebih kecil dari 0,05 . Hal ini pengaruh kepemimpinan berbanding lurus terhadap kinerja karyawan, artinya semakin baik kepemimpinan di suatu perusahaan maka semakin baik pula kinerja karyawannya.

Koefisien regresi hubungan industrial (X3) menunjukkan nilai sebesar 0,509 hal ini berarti menunjukkan arah pengaruh hubungan industrial (X3) terhadap kinerja karyawan (Y) adalah signifikan posited dengan nilai signifikansinya 0,000 lebih kecil dari 0,05 . Hal ini pengaruh hubungan industrial berbanding lurus 
terhadap kinerja karyawan, artinya semakin baik hubungan industrial dalam suatu perusahaan maka semakin baik pula kinerja karyawannya.

Koefisien determinasi $\mathrm{R}^{2}$ menunjukkan ukuran proporsi keragaman total nilai variabel terikat $(\mathrm{Y})$ yang dapat dijelaskan oleh nilai variabel bebas $(\mathrm{X})$ melalui hubungan linier disajikan pada tabel 6 .

Tabel 5.

Koefisien Determinasi

\begin{tabular}{llllllr}
\hline Model & $\mathbf{R}$ & R Square & Adjusted R Square & $\begin{array}{l}\text { Std. Error } \\
\text { Estimate }\end{array}$ & of the \\
\hline 1 & $.819^{\mathrm{a}}$ & .670 & .661 & & .58363 \\
\hline Sumber: Data diolah, 2018 & & & &
\end{tabular}

Berdasarkan Tabel 5 dapat dilihat nilai Rsquare sebesar 0,670. Hal ini berarti bahwa sebesar $67 \%$ variabel kinerja karyawan dijelaskan oleh diklat, kepemimpinan dan hubungan industrial. Sisanya sebesar $23 \%$ dijelaskan oleh variabel lain di luar model penelitian ini.

Koefisien regresi diklat (X1) menunjukkan nilai sebesar 0,203 hal ini berarti menunjukkan arah pengaruh diklat (X1) terhadap kinerja karyawan (Y) adalah signifikan positif dengan nilai signifikansinya 0,045 lebih kecil dari 0,05 . Hal ini pengaruh diklat berbanding lurus terhadap kinerja karyawan, artinya semakin baik diklat yang diberikan oleh perusahaan maka semakin baik pula kinerja karyawannya.

Hasil ini sejalan dengan penelitian yang dilakukan oleh Dartha (2017), dan Pojoh dkk.(2014). Baik Dartha (2017) dan Pojoh dkk, (2014) berpendapat sama bahwa diklat berpengaruh positf dan signifikan terhadap kinerja karyawan. Hanifah dan Nuridin (2017), melakukan penelitian tentang pengaruh diklat dan motivasi terhadap kinerja karyawan. Penelitian mereka menunjukkan hasil bahwa diklat 
berpengaruh lebih dominan terhadap kinerja karyawan daripada motivasi. Wiratama dan Sintaasih (2013), melakukan penelitian mengenai kepemimpinan, diklat, dan disiplin kerja terhadap kinerja karyawan, menunjukan ketiga variabel tersebut berpengaruh signifikan terhadap kinerja karyawan. Purba (2016), melakukan penelitian mengenai pengaruh pelatihan, gaya kepemimpinan, dan kinerja pegawai menunjukkan bahwa variabel pelatihan berpengaruh lebih dominan terhadap kinerja karyawan daripada gaya kepemimpinan.

Koefisien regresi kepemimpinan (X2) menunjukkan nilai sebesar 0,291 hal ini berarti menunjukkan arah pengaruh kepemimpinan (X2) terhadap kinerja karyawan (Y) adalah signifikan positif dengan nilai signifikansinya 0,004 lebih kecil dari 0,05. Hal ini pengaruh kepemimpinan berbanding lurus terhadap kinerja karyawan, artinya semakin baik kepemimpinan di suatu perusahaan maka semakin baik pula kinerja karyawannya.

Hasil penelitian ini sejalan dengan penelitian yang dilakukan oleh Raharjo dan Sedyaningsih (2014), pada penelitiannya yang yang meneliti pengaruh kepemimpinan, motivasi, dan lingkungan kerja terhadap kinerja karyawan pada PT. Citra Sukses Eratama Tanggerang, menunjukkan bahwa ketiga variabel berpengaruh positif dan signifikan terhadap kinerja karyawan. Wijayanti (2012), dalam skripsinya yang berjudul pengaruh kepemimpinan dan motivasi kerja terhadap kinerja karaywan pada PT. Daya Anugerah Semesta Semarang, menunjukkan bahwa variabel kepemimpinan berpengaruh positf dan signifikan daripada kinerja karyawan. Yuliana (2016), dalam penelitiannya yang berjudul pengaruh kepemimpinan, motivasi, dan lingkungan kerja terhadap kinerja 
karyawan pada PT. BCA Syariah Semarang, menunjukkan bahwa variabel kepemimpinan berpengaruh paling dominan terhadap kinerja karyawan daripada motivasi dan lingkngan kerja. Ardianta dan Supartha (2014), dalam penelitiannya yang berjudul pengaruh diklat, kepemimpinan, dan penerapan budaya organisasi terhadap kinerja karyawan, menunjukkan, bahwa ketiga variabel yang diteliti berpengaruh positif dan signifikan terhadap kinerja karyawan.

Koefisien regresi hubungan industrial (X3) menunjukkan nilai sebesar 0,509 hal ini berarti menunjukkan arah pengaruh hubungan industrial (X3) terhadap kinerja karyawan (Y) adalah signifikan posited dengan nilai signifikansinya 0,000 lebih kecil dari 0,05 . Hal ini pengaruh hubungan industrial berbanding lurus terhadap kinerja karyawan, artinya semakin baik hubungan industrial dalam suatu perusahaan maka semakin baik pula kinerja karyawannya.

Hasil penelitian ini sejalan dengan penelitian yang dilakukan oleh Sriathi (2016), yang melakukan penelitian mengenai variabel yang mempengaruhi kinerja karyawan. Dengan meneliti variabel stress kerja dan hubungan industrial. Kesimpulan Sriathi (2016) menunjukkan bahwa stress kerja dan hubungan industrial berpengaruh signifikan terhadap kinerja karyawan baik secara parsial maupun simultan, dimana hubungan industrial berpengaruh lebih dominan. Hasil penelitian yang sama juga dikemukakan oleh Roz (2016), dalam penelitiannya yang meninjau hubungan industrial, gaya kepemimpinan transformasional dan kompensasi sebagai variabel bebas, menunjukkan bahwa hubungan industrial berpengaruh positif dan signifikan terhadap kinerja karyawan sedangkan kepemimpinan transformasional dan kompensasi memperkuat pengaruhnya. 
Hasil penelitian ini menunjukkan bagaimana pengaruh antara diklat, kepemimpinan dan hubungan industrial terhadap kinerja karyawan. Berdasarkan temuan tersebut maka hasil penelitian ini mampu memperkaya faktor-faktor yang mempengaruhi kinerja karyawan yang ada di suatu perusahaan oleh beberapa ahli terdahulu serta mendukung studi-studi empiris terkait pengetahuan manajemen sumber daya manusia.

Berdasarkan hasil penelitian pada penelitian ini ada implikasi praktis yang dihasilkan. Berdasarkan persamaan regresi linier berganda variabel hubungan industrial memiliki pengaruh paling dominan dalam mempengaruhi kinerja karyawan. Hal ini menjelaskan bahwa antara setiap pemangku kepentingan dengan karyawan di perusahaan berkewajiban menjaga hubungan industrial yang harmonis di perusahaan. Praktek hubungan industrial yang kondusif dan harmonis menciptakan ketenangan bekerja sehingga dapat meminimalisir gangguan dan permasalah di lingkungan kerja. Ketika hubungan industrial ini terjaga dengan baik maka akan terjadi peningkatan produktivitas karyawan. Peningkatan produktivitas karyawan akan mempengaruhi peningkatan kinerja perusahaan. Kinerja perusahaan yang baik lebih mampu meningkatkan kesejahteraan karyawan.

Adapun keterbatasan dalam penelitian ini dapat dijelaskan bahwa penelitian hanya dilakukan di lingkungan kerja perusahaan jasa (swasta). Maka hasil penelitian ini tidak bisa digeneralisasi pada setiap lingkungan kerja. Pada penelitian selanjutnya diharapkan juga peneliti mampu melakukan penelitian di lingkungan kerja pemerintahan karena dari segi diklat, kepemimpinan maupun hubungan industrial di lingkungan kerja swasta dan pemerintahan jelas berbeda. 
A.A. Hastya Priyamedha, Pengaruh Diklat, Kepemimpinan...

\section{SIMPULAN DAN SARAN}

Berdasarkan hasil pembahasan penelitian yang telah dilakukan, maka dapat disimpulkan bahwa diklat berpengaruh positif dan signifikan terhadap kinerja karyawan. Artinya semakin baik diklat yang diberikan oleh perusahaan maka semakin baik pula kinerja karyawannya.

Kepemimpinan berpengaruh positif dan signifikan terhadap kinerja karyawan. Artinya semakin baik kepemimpinan yang dimiliki oleh perusahaan maka semakin baik pula kinerja karyawannya. Hubungan industrial berpengaruh positif dan signifikan terhadap kinerja karyawan. Artinya semakin baik hubungan industrial pada suatu perusahaan maka semakin baik pula kinerja karyawannya.

Saran yang dapat diberikan berdasarkan kesimpulan yang didapat adalah menurut para karyawan diklat yang diberikan perusahaan dinilai sudah baik, namun berdasarkan jawaban karyawan terhadap konstruk diklat terdapat pada kemampuan instruktur menyampaikan materi dinilai paling rendah. Penting untuk diketahui perusahaan agar kedepannya lebih selektif lagi memilih instruktur dalam memeberikan diklat (pelatihan) disarankan agar menggunakn instruktur yang telah berkompeten pada bidangnya dan telah memiliki sertifkat kompetensi. Hal ini penting agar penyampaian materi kepada karyawan tersalurkan dengan baik dan memberikan manfaat yang baik juga untuk karyawan.

Kepemimpinan di perusahaan ini dinilai sudah baik. Namun atasan menjaga lingkungan kerja kondusif dinilai paling rendah oleh karyawan. Hal ini penting untuk diketahui kedepannya agar tercipta lingkungan kerja yang kondusif dan tenag guna peningkatan produktivitas karyawan meningkat. Apabila produktivitas 
meningkat maka kinerja karyawan yang dihasilkan untuk perusahaan pun akan semakin baik. Secara garis besar hubungan industrial di perusahaan dinilai baik. Namun karyawan merasakan bahwa adanya hambatan menyampaikan saran oleh karyawan untuk atasan. Hambatan-hambatan ini terkadang menjadi hal yang membuat kinerja karyawan menurun, saran dari karyawan seharusnya diterima dengan baik guna evaluasi proses kerja di dalam lingkungan perusahaan. Hubungan industrial menjadi faktor paling dominan dalam mempengaruhi kinerja karyawan di perusahaan ini maka disarankan agar perusahaan dapat dengan mudah menerima saran yang diberikan oleh karyawan. Kinerja karyawan di perusahaan ini dinilai baik. Namun karyawan menilai pekerjaannya di perusahaan ini belum memenuhi standar kuantitas perusahaan. Maka disarankan kepada perusahaan untuk mencari informasi penyebab terjadinya hal ini. Banyak faktor yang menyebabkan standar kuantitas yang belum bisa dipenuhi, seperti kelelahan bekerja dan beban kerja berlebihan. Ketika hal ini terjadi maka tidak bisa dipungkuri kinerja karyawan di perusahaan ini akan menurun.

Penelitian dimasa mendatang diharapkan untuk mengembangkan empiris dan teori mengenai pengaruh kinerja karyawan pada bidang ilmu mananjemen sumber daya manusia. Variabel yang disarankan adalah motivasi, kompensasi financial, penerapan budaya organisasi dan kepuasan kerja.

\section{REFERENSI}

Ardianta, I W, dan Supartha, I W, G.. (2014). "Pengaruh Diklat, Kepemimpinan dan Penerapan Budaya Organisasi Terhadap Kinerja Karyawan”. E-Jurnal Manajemen Universitas Udayana, 3(9), hal. 2685-2697.

Dartha, I K. (2017). "Pengaruh Pendidikan dan Pelatihan (Diklat) Terhadap Kinerja PegawaiNegeri Sipil Pada Sekretariat Daerah Kota Malang”. Jurnal 
Evanita, L. (2016). Disiplin Kerja, Gaya Kepemimpinan, Pelatihan dan Kinerja Karyawan RSUD Lubuk Sikapang, Tesis Magister Manajemen pada Program Pascasarjana Universitas Esa Unggul, Jakarta

Hanifah, G., \& Nuridin. (2017). "Pengaruh Diklat dan Motivasi Terhadap Kinerja Karyawan Pada PT. Synergis Global Performa”. Jurnal Manajemen Bisnis Krisnadwipayana, 5(1), hal. 1-15.

Kuzu O, H, and Ozilhan D (2014). "The Effect of Employee Relationships and Knowledge Sharing on Employees' Performance: An Empirical Research on Service Industry". Sciencedirect Procedia - Social and Behavioral Sciences, 109, pp. $1370-1374$

Manurung, Y. V. 2013. Pengaruh Pelatihan, Motivasi, Kepemimpinan, dan Budaya Organisasi terhadap Kinerja Karyawan PT. Karya Dewi Putra, Tesis Magister Program Pascasarjana Universitas Terbuka, Jakarta

Muda, I., Rafiki, A., \& Harahap, M. R. (2014). Factors Influencing Employees' Performance: A Study on the Islamic Banks in Indonesia. International Journal of Business and Social Science, 5(2), pp. 73-80.

Nassazi, A. 2013. Effects of Training on Employee Performance, Thesis. University of Applied Sciences, Uganda

Ningsih, N. O., Musadieg, N. A. dan Utami, H. N. (2015) "Peran Serikat Pekerja dan Manajemen dalam Membina Hubungan Industrial Studi Pada PG. Kebon Agung Malang”. Jurnal Administrasi Bisnis, 24(1), hal. 1-10

Nurlaila, dan Fatyandri A. N. (2018). “Analisis Faktor-Faktor yang Mempengaruhi Kinerja Karyawan pada Hotel Berbintang 4 di Kota Batam”. Journal of Accounting and Management Innovation, 2(1), hal. 90-106

Plessis A. (2016). "The Importance Of Training and Education For New Zealand Enterpreneurs To Be Succesful : Some Empirical Evidence". Journal Of Community Positive Practices, 16(2) pp.18-38

Pojoh, T. P., Tewal, B., \& Moniharapon, S. (2014). "Pengaruh Pendidikan dan Pelatihan Terhadap Kinerja Karyawan pada PT PLN Wilayah Sulttengo". Jurnal EMBA 2(4), hal. 424-434.

Purba, J. H., (2016). "Pengaruh Pelatihan dan Gaya Kepemimpinan terhadap Kinerja Pegawai pada PT. Perkebunan Nusantara Tanjung Morawa". Jurnal Ilmiah Methonomi 2(2), hal. 46-58.

Rahardjo, G., \& Sedyaningsih, S. (2014). "Pengaruh Kepemimpinan, Motivasi Dan Lingkungan Kerja Terhadap Kinerja Karyawan Pada PT.Citra Sukses Eratama, Tangerang". Jurnal Bisnis dan Manajemen Eksekutif, 1(1), hal.17

Roz, K. (2016). "Pengaruh Hubungan Industrial Terhadap Kinerja karyawan dengan Gaya Kepemimpinan Transformasional dan Kompensasi sebagai 
Variabel Moderasi”. Prosiding Seminar Nasional Manajemen Teknologi XXV Program Studi MMT-ITS. hal. 1-8

Rivai, Veithzal, Ramly M, Mutis T, dan Arafah W. (2009). Manajemen Sumber Daya Manusia Untuk Perusahaan Dari Teori Ke Praktik Edisi Ketiga. Jakarta: Rajawali Pers.

Sawitri, D. D, Suswati E, and Huda K. (2016) "The Impact of Job Satisfaction, Organization Commitment, Organization Citizenship Behavior (OCB) On Employees Performance". International Journal of Organizational Innovation, 9(2), pp. 24-45.

Setiana, A. A., \& Siswandoko, T. (2009). "Analisis Pengaruh Pendidikan dan Pelatihan serta Motivasi terhadap Kinerja Karyawan”. Jurnal Ekonomi dan Industri, 2(16), hal. 36-42.

Sequeira A, H, and Drithi A. (2015). "Employee Relation and Its Impact On Employee Performance: A Case Study". Research Gate, pp. 1-17.

Shobirin M., Minarsih M. M., dan Fathoni A. (2016). "Analisis Pengaruh Kepemimpinan, Komitmen Organisasi, dan Kepuasan Kerja Terhadap Keinginan Pindah Kerja Karyawan PT. Bank BTPN Mitra Usaha Rakyat Area Semarang”. Journal of Management, 2(2), hal 1-18

Sriathi, A. (2016). "Analisis Kinerja Karyawan di The Villas Bali and SPA, KutaBadung”. OJS Universitas Udayana, 5(2), hal. 1-11

Subandi, M. (2016). "Pengaruh Pendidikan dan Pelatihan (Diklat) terhadap Kompetensi Pegawai Dinas Perhubungan Kabupaten Kertanegara". Jurnal Ilmu Sosial Mahakam, 5(1), hal. 22-36

Thao L. T., and Hwang J., (2015). "Factors Effecting Employee's Perfromance: Evidence From Petrovietnam Engineering Consultancy". J.S.C. ejbss.

Undang-Undang Republik Indonesia Nomor 13 Tahun (2003) Tentang Ketenagakerjaan.

Wibowo. (2007). Manajemen Kinerja dan Kompensasi Edisi Keempat. Jakarta: Rajawali Pers.

Wijayanti, D. W. (2012). Pengaruh Kepemimpinan dan Motivasi Kerja terhadap Kinerja Karyawan pada PT Daya Anugrah Semesta Semarang, Skripsi Fakultas Ekonomi Jurusan Manajemen Universitas Negeri Semarang, Semarang 
A.A. Hastya Priyamedha, Pengaruh Diklat, Kepemimpinan...

Wiratama, I. N., \& Sintaasih, D. K. (2013). "Pengaruh Kepemimpinan, Diklat, dan Disiplin Kerja Terhadap Kinerja Karyawan PDAM Tirta Manutama Kabupaten Badung". Jurnal Manajemen, Strategi Bisnis, dan Kewirausahaan, 7(2), hal. 126-134.

Yuliana R. (2016). "Pengaruh Kepemimpian Motivasi, dan Lingkungan Kerja Terhadap Kinerja Karyawan Studi Kasus Pada PT. BCA Syariah Semarang”. Jurnal STIE Semarang, 8(3), hal. 201-218. 